University of Nebraska - Lincoln

DigitalCommons@University of Nebraska - Lincoln

USDA National Wildlife Research Center - Staff Publications
U.S. Department of Agriculture: Animal and Plant Health Inspection Service

December 2003

\title{
Wolf Depredation Trends and the Use of Fladry Barriers to Protect Livestock in Western North America
}

\author{
Marco Musiani \\ University of Calgary \\ Charles Mamo \\ Southern Alberta Conservation Cooperative \\ Luigi Boitani \\ University of Rome, Viale dell'Universita, Rome, Italy \\ Carolyn Callaghan \\ Central Rockies Wolf Project \\ C. Cormack Gates \\ University of Calgary, Alberta, Canada \\ See next page for additional authors
}

Follow this and additional works at: https://digitalcommons.unl.edu/icwdm_usdanwrc

Part of the Environmental Sciences Commons

Musiani, Marco; Mamo, Charles ; Boitani, Luigi; Callaghan, Carolyn; Cormack Gates, C.; Mattei, Livia; Visalberghi, Elisabetta; Breck, Stewart W.; and Volpi, Giulia, "Wolf Depredation Trends and the Use of Fladry Barriers to Protect Livestock in Western North America" (2003). USDA National Wildlife Research Center - Staff Publications. 620.

https://digitalcommons.unl.edu/icwdm_usdanwrc/620

This Article is brought to you for free and open access by the U.S. Department of Agriculture: Animal and Plant Health Inspection Service at DigitalCommons@University of Nebraska - Lincoln. It has been accepted for inclusion in USDA National Wildlife Research Center - Staff Publications by an authorized administrator of DigitalCommons@University of Nebraska - Lincoln. 


\section{Authors}

Marco Musiani, Charles Mamo, Luigi Boitani, Carolyn Callaghan, C. Cormack Gates, Livia Mattei, Elisabetta Visalberghi, Stewart W. Breck, and Giulia Volpi 


\title{
Wolf Depredation Trends and the Use of Fladry Barriers to Protect Livestock in Western North America
}

\author{
MARCO MUSIANI, ${ }^{*} \S \S$ CHARLES MAMO,$\dagger$ LUIGI BOITANI, $\ddagger$ CAROLYN CALLAGHAN, $\S$ \\ C. CORMACK GATES, ${ }^{*}$ LIVIA MATTEI, ${ }^{* *}$ ELISABETTA VISALBERGHI, $\dagger \dagger$

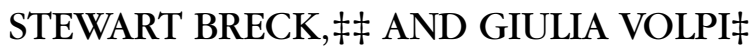

${ }^{*}$ Faculty of Environmental Design, The University of Calgary, 2500 University Drive NW, Calgary, Alberta T2N 1N4, Canada †Southern Alberta Conservation Cooperative, Box 314, Cremona, Alberta TOM OR0, Canada ‡Department of Animal and Human Biology, University of Rome, Viale dell'Universita' 32, Rome, Italy $\S$ Central Rockies Wolf Project, 713 Main Street, Canmore, Alberta, Canada

${ }^{* *}$ Corpo Forestale dello Stato, Ministero delle Politiche Agricole e Forestali, Pescara, Italy t†Istituto di Scienze e Tecnologie della Cognizione, National Research Council, Via Aldrovandi 16b, 00197 Rome, Italy



\begin{abstract}
In Alberta, Canada (1982-2001), and in Idabo, Montana, and Wyoming, United States (19872001), wolves (Canis lupus) killed various domestic animals, among which the major prey were sheep in the United States $(68 \%, \mathrm{n}=494)$ and cattle in Canada $(95 \% ; \mathrm{n}=1633)$. Under recovery programs, the wolf population increased in the United States, and depredation events increased proportionately. In both countries, the number of domestic animals killed each year was correlated with the number of wolves killed by government authorities for depredation management. We tested the ability of antiwolf barriers made of flags banging from ropes to impede wolf access to food and livestock. In 18 experiments, barriers prevented captive wolves $(\mathrm{n}=9)$ from accessing food for up to 28 bours and allowed daily separation of wolves to administer contraceptive pills to a female wolf. Barriers prevented access by wild wolves to 100- $\mathrm{m}^{2}$ baited sites during two 60-day tests. We also set barriers around three cattle pastures. In Alberta during two 60-day trials on 25-ha pastures, wolves approached barriers on 23 occasions but did not cross them, and no cattle were killed. Wolves killed cattle on neighboring ranches during the trials and before and after the trials on the tested ranches. In Idabo four radiocollared wolves crossed barriers and killed cattle in a 400-ha ranch after 61 days of barrier exposure. Our results suggest that antiwolf barriers are effective in deterring captive and wild wolves for $>1$ and $\geq 60$ days, respectively, and that wild wolves switch to alternative livestock when excluded from one berd of livestock. Our depredation data indicate that protecting livestock from wolves reduces the necessity for killing wolves. Barriers could play a role among the limited set of preventive measures available and offer a cost-effective mitigation tool for the problem of livestock depredation on a local scale.
\end{abstract}

Tendencias en la Depredación por Lobos y el Uso de Barreras para Proteger Ganado en Norte América Occidental

Resumen: En Alberta, Canadá (1982 a 2001) y en Idabo, Montana y Wyoming, Estados Unidos (1987 a 2001), los lobos (Canis lupus) mataron a varios animales domésticos en su mayoría ovejas ovejas en Estados Unidos (68\%, $\mathrm{n}=494)$, y ganado vacuno en Canadá $(95 \% ; \mathrm{n}=1633)$. La población de lobos incrementó en Estados Unidos bajo programas de recuperación y los casos de depredación incrementaron proporcionalmente. En ambos países, el número de animales domésticos depredados cada año se correlacionó con el número de lobos matados por autoridades gubernamentales para la gestión de la depredación. Probamos la efectividad de barreras contra lobos hechas de banderas colgando de cuerdas para impedir el acceso de lobos

§§email mmusiani@ucalgary.ca

Paper submitted February 3, 2003; revised manuscript accepted May 18, 2003. 
a alimento y ganado. En 18 experimentos, las barreras previnieron que los lobos cautivos $(\mathrm{n}=9)$ accedieran al alimento por hasta 28 boras y permitieron la separación diaria de los lobos para administrar píldoras anticonceptivas a una hembra. Las barreras evitaron el acceso de lobos silvestres a sitios de $100 \mathrm{~m}^{2}$ cebados durante dos pruebas de 60 días. También establecimos barreras alrededor de tres potreros para ganado vacuno. En Alberta durante dos ensayos de 60 días en potreros de 25 ha, los lobos se acercaron a las barreras en 23 ocasiones pero no las atravesaron, y ninguna res fue depredada. Los lobos depredaron al ganado en ranchos vecinos durante las pruebas y antes y después de las pruebas en los ranchos en que se llevaron a cabo. En Idabo, cuatro lobos con collares con radio atravesaron las barreras y mataron ganado en un rancho de 400 ba 61 días después de la exposición a barreras. Nuestros resultados sugieren que las barreras antilobo son efectivas para disuadir a lobos cautivos y silvestres por $>1$ y $\geq 60$ días respectivamente y que lobos silvestres cambian a ganado alternativo cuando son excluidos de un bato de ganado. Nuestros datos de depredación indican que la protección de ganado reduce la necesidad de matar lobos. Las barreras podrían jugar un papel entre el limitado conjunto de medidas disponibles y ofrecer una berramienta de mitigación costo-efectiva para el problema de la depredación de ganado a escala local.

\section{Introduction}

During the last 20 years, increasing attention has been directed toward large-carnivore conservation (Mech 1995; Haber 1996; Kellert et al. 1996). In many areas, however, carnivores come into conflict with humans and their economic interests, such as livestock production (Woodroffe 2000; Sillero-Zubiri \& Laurenson 2001). Consequently, scientists and managers are increasingly engaged in efforts to maintain populations of carnivores in coexistence with people (Bangs et al. 1998; Linnell et al. 2000; Madhusudan \& Karanth 2002; Treves et al. 2002).

In the ranchlands of North America, wolves were exterminated during and after the European settlement (Young \& Goldman 1944). Wolves (Canus lupus) are currently recolonizing their original range, and recovery has been supported by large sectors of the public (Kellert et al. 1996; Williams et al. 2002). During 1995 and 1996, the U.S. Fish and Wildlife Service and Canadian biologists captured wolves in western Canada and reintroduced them to Yellowstone National Park and central Idaho. The reintroduction program was successful (Fritts et al. 1997; Bangs et al. 1998).

Wolves typically prey on all ungulate species within their distributional range, including domestic animals when they are sympatric (Young \& Goldman 1944; Mech 1970; Meriggi \& Lovari 1996). Competition between humans and wolves for ungulates is an ancient struggle originating with hunter societies (Boyd et al. 1994; Orians et al. 1997) then continuing with the domestication of some wild ungulates (Kay 1998). The potential for conflict between wolves and humans exists especially in rural areas, where livestock production is a major economic activity (Mech 1998; Mech et al. 2000). Recent wolf recovery in North America has contributed to wolves moving into such rural areas (Mech 1995; Bangs et al. 1998; Parsons 1998; Treves et al. 2002), where conflicts and the associated costs of livestock protection and lethal control of wolves are increasing (Mech 1998).
Some nonlethal techniques are available for managing predation risk from wolves. Guard dogs are used effectively in Europe and northern Asia, where shepherds and ranchers work directly with the dogs (Hansen \& Smith 1999; Ciucci \& Boitani 1998; Smith et al. 2000a; Coppinger \& Coppinger 2001). North American ranchers use guard dogs less frequently. In addition, dogs are often left alone to guard livestock, and some evidence suggests that this makes guard dogs less efficient (Andelt \& Hopper 2000). Finally, wolves can kill dogs, further exacerbating negative human attitudes toward wolves (Fritts \& Paul 1989; Kojola \& Kuittinen 2002; Treves et al. 2002). Other guard animals remain largely untested against wolves, but a few anecdotes suggest little benefit (Bangs \& Shivik 2001).

Another option ranchers have for controlling wolf depredation is to construct substantial barriers or electric fences to exclude wolves from livestock. These barriers are often expensive, and electric fences are typically difficult to maintain (Gipson \& Paul 1994). Other methods used to manage depredation involve translocating wolves from areas of high livestock production to remote areas (Fritts et al. 1984; Bangs et al. 1998; Bangs \& Shivik 2001), aversive conditioning of wolves to livestock (Fritts et al. 1992), and wolf deterrents and repellents. These approaches are expensive and normally provide only temporary relief from depredation (Linnell et al. 1997; Smith et al. 2000b).

Alternatively, producers or government authorities may resort to killing wolves (Fritts et al. 1992; Cluff \& Murray 1995; Bangs et al. 1998; Mech 1998). Lethal control is strongly opposed by large sectors of the public in Canada (Struzik 1993) and somewhat opposed in the United States (Haber 1996; Naughton et al. 2003 [this issue]) for animal welfare and ecological reasons. Opponents to wolf control argue that wolves play a pivotal role in natural ecosystems (Ripple et al. 2001; Jedrzejewski et al. 2002) and that current lethal-control practices are ineffective and inhumane (Berg 1998). 
The technique known as fladry (Okarma 1993), in which flags hang from ropes stretched a short distance above the ground, was traditionally used to hunt wolves in Eastern Europe and Russia. Fladry is not effective on other mammals (Okarma \& Jedrzejewski 1997; Shivik et al. 2003 [this issue]). Musiani and Visalberghi (2001) documented avoidance of fladry by captive wolves and described optimal design attributes for effectively deterring wolves.

Here, we describe trends in wolf depredation on livestock in Alberta, Canada, during the 1980s and 1990s and compare them with trends in Idaho, Montana, and Wyoming in the United States during 1987-2001. We report on experiments to evaluate the effectiveness of fladry for deterring wolves from accessing food in captivity and in the wild and for separating social groups of wolves in captivity. Finally, we document the use of fladry barriers in field situations in Alberta and Idaho for protecting livestock from depredation by wild wolves.

\section{Study Area}

The study area encompassed parts of the northwestern United States-the states of Idaho, Montana, and Wyoming-and Alberta, Canada. In this region, human settlements and towns are interspersed with undeveloped areas, some of which are protected in national and state or provincial parks. Outside protected areas there is a mixture of public and private lands in which agriculture and forestry are the most important land uses. Throughout the study area, livestock production is an important economic activity on private and public grazing lands. Large predators and mesopredators include the grizzly bear (Ursus Arctos), black bear (U. americanus), puma (Felis concolor), gray wolf, feral domestic dog (Canis domesticus), and coyote (Canis latrans). Wolves have continuously occupied large areas of Alberta but were extirpated from most of the U.S. portion of the study area in the early 1900s (Young \& Goldman 1944). In 1995 wolves were reintroduced to the U.S. area. Northwestern Montana experienced a natural recolonization of wolves from Canada. Important wolf prey such as the bison (Bison bison), moose (Alces alces), elk (Cervus Canadensis), white-tailed deer (Odocoileus virginianus), mule deer (Odocoileus hemionus), and pronghorn (Antilocapra Americana) are found throughout the wolf's range.

\section{Methods}

\section{Depredation Trends}

We examined data on wolf depredation collected by the government of Alberta for the whole province from April
1982 to April 1996. Data were available separately for the eastern slopes of the Rocky Mountains in southwestern Alberta $\left(11,000 \mathrm{~km}^{2}\right)$ for the years 1990-2001. The U.S. Fish and Wildlife Service provided wolf-depredation data and population estimates for Idaho, Montana, and Wyoming from 1987 to 2001. Data included domestic animals that upon inspection by government officers were confirmed as being killed (information available for Canada and the United States) or injured (available for Canada) by wolves. Data also included wolves killed by government authorities engaged in depredation management. The data from the United States and southwestern Alberta also included information on whether the domestic-animal killing event occurred on private or public land. Canadian government officials identified age classes of cattle killed or injured by wolves in southwestern Alberta, although the total number of wolves killed there was not recorded.

Depredation data represent the minimum number of animals killed or injured. In remote areas, carcasses of domestic animals may not be found or may be found after decomposition and scavenging preclude assessment of the cause of death (Bangs \& Shivik 2001). In addition, ranchers are not required to report depredation events unless they file a compensation claim for damage. In Idaho, Montana, and Wyoming, all confirmed losses from wolf depredation may be compensated (Phillips \& Smith 1998). In Alberta, compensation programs are in place for losses of cattle, sheep, hogs, goats, and bison (Alberta Conservation Association 2002). Consequently, data on losses of other livestock, such as horses, lamas, and alpacas, are scarce. In the United States, all wolves killed by people must be reported, but often they are not (Treves et al. 2002). In Alberta, wolves are considered a big game species and may be legally taken by hunters (reporting not required prior to 2000) or registered trappers. Finally, landowners can kill wolves in Alberta without restriction on their properties and within $8 \mathrm{~km}$ of their land, and they are not required to report the number killed.

\section{Experiments on Captive Wolves}

During 2000 and 2001, we conducted 18 experiments on two wolf groups and three single adult wolves housed in five $50 \times 50 \mathrm{~m}$ enclosures in a captive-breeding facility located in Popoli, Abruzzo, Italy (Riserva Naturale Monte Rotondo). One group contained one male, one female, and two pups. Pups were born in May 2000, and their family group was tested between October 2000 and April 2001. Another group contained one male and one female. The wolves were from genetic stock originating from Siberia, Bulgaria, or Italy.

We set up fladry following the method of Musiani and Visalberghi (2001). Plastic flags measuring $50 \times 10 \mathrm{~cm}$ were sewn at $50-\mathrm{cm}$ intervals on a 0.2 -cm-diameter nylon rope. The rope was suspended $50 \mathrm{~cm}$ above the ground 
on metal rebar posts placed at 30-m intervals. The cost for commercially manufactured fladry was approximately US\$0.19/m.

We started experiments around 1000 hours, with at least 7 days between experiments. In each trial, a fladry barrier was erected to divide the enclosure into two equal parts. Each experiment consisted of three phases, including a 45-minute baseline period (baseline), a period of varying duration in which a fladry barrier was set between wolves and food or was used to separate wolves from a companion and food (fladry phase), and a 45-minute post-fladry period. The fladry barriers were set and removed by the keepers, who were supervised by one researcher. Access to the enclosures was limited to the keepers. Wolves were not habituated to interactions with the public. All experiments were videotaped (DCRTRV320 Digital Camcorder, Sony) with infrared emission units for nocturnal observations (HLV-IRH2 Night Shot Infrared Emission Unit, Sony), and experiments lasted up to 5 days and nights. The recording equipment was operated by the researcher and housed in camouflaged tents permanently erected $5 \mathrm{~m}$ away from the enclosures.

We used fladry to separate a male and a female so that the female could be treated with an oral contraceptive for 8 consecutive days. The pill was hidden in food (meat ration). The male wolf was also fed during this period. Keepers separated the pair by luring them to food provided as usual at two opposite sides of the enclosure. They were able to erect fladry in $<15$ minutes. Fladry was removed after the contraceptive was consumed, typically within 10 minutes.

Videotapes were analyzed twice in slow motion by G.V., who recorded occurrences of wolves crossing the position of the fladry line during all experimental phases. Also recorded was the duration of the following behaviors: wolf location within two zones (within $6 \mathrm{~m}$ of the fladry line and between 6 and $15 \mathrm{~m}$ of the fladry line), sniffing an object or the air, and moving (walking, trotting, or galloping). Sniffing and moving behaviors were recorded separately within two zones (within $2 \mathrm{~m}$ of the fladry line and between 2 and $6 \mathrm{~m}$ of the fladry line). The video camera's view was limited to $15 \mathrm{~m}$ on either side of the fladry line, so wolf activity outside these bounds was not recorded.

\section{Bait Station Trials}

In Alberta during the winters of 2001 and 2002, we set fladry $(10 \times 10 \mathrm{~m})$ around two sites where we previously had attracted wild wolves to feed on wild ungulates that were accidentally killed in collisions with vehicles. Bait sites were located in a protected area where livestock were not present (Peter Lougheed Provincial Park). Weather conditions and the continuous presence of snow allowed for tracking of wolves. Snow fell frequently, allowing us to distinguish between old ( $>72$ hours old) and fresh tracks. The enclosures and an area up to $500 \mathrm{~m}$ surrounding them were checked for wolf tracks every 72 hours for 180 days. The 180-day period was divided equally into baseline, fladry, and post-fladry phases. One researcher (occasionally two) conducted surveys on foot. During each visit, we checked for consumption of carcasses at baited sites and recorded carcass condition. We replenished the carcass with ungulate parts if more than half of it had been consumed. Temperatures constantly below freezing precluded decomposition. We recorded occurrences of wolf feeding at baits and tracks indicating approaches by wolves to within 1-50 $\mathrm{m}$ of bait enclosures.

\section{Trials on Cattle Pastures}

In Alberta during the winters of 2001 and 2002, we set fladry around two pastures of approximately 25 ha, each containing 100 cattle. The fladry barrier was positioned $2 \mathrm{~m}$ outside conventional barbed-wire livestock fences, which prevented cattle from damaging or ingesting the flags. As in the bait station trials, we relied on snow tracking to detect the appearance of wolves inside or outside the fladry barrier and divided the 180-day period equally into baseline, fladry, and post-fladry phases.

In Idaho during the summer of 2002, we set approximately $10 \mathrm{~km}$ of fladry around a 400-ha ranch containing almost 400 cattle. Fladry was attached to the existing barbed-wire fence that surrounded the ranch. In this situation, cattle could damage or ingest some flags. The wolf pack in the area contained at least four individuals that had been captured and radiocollared (VHF collars, Telonics, Meza, Arizona) by the U.S. Fish and Wildlife Service more than 1 year prior to the experiment. One of their objectives was to monitor wolf movements in relation to depredation on livestock. We monitored the collared wolves daily with radiotelemetry from the ground. This allowed us to determine whether monitored wolves entered the ranch. We walked the entire fladry line to maintain it every 72 hours. We recorded the number of days fladry was set before wolves crossed it. Contrary to the field trials conducted in Canada, snow was not present in Idaho during the experiment. All other environmental variables were similar for trials conducted in Canada and the United States.

\section{Statistical Analysis}

Data are presented as the number of occurrences, mean per subject or duration per hour \pm standard deviation (SD). We used analysis of variance (ANOVA) and leastsquares simple linear regression to test correlation among data on yearly occurrences of depredation, wolf mortality, and wolf density. The chi-square test was used to compare frequencies. We tested differences among the three experimental phases across individuals with the Friedman test and between pairs of phases with the 
Wilcoxon signed-ranks test. All tests were two-tailed, and the significance cut-off was $p<0.05$.

\section{Results}

\section{Depredation Data}

In Alberta, Canada, from April 1982 to April 1996 (14-year series), known wolf depredation resulted in 2086 domestic animals killed, including cattle (78\%), dogs (9\%), horses (5\%), sheep (5\%), and chickens, bison, goats, geese, and turkeys (each $<2 \%$ ). During this period, government authorities killed 795 wolves to manage depredation. In Idaho, Montana, and Wyoming, from 1987 to 2001 ( 15 years), wolves killed 728 domestic animals, including sheep (68\%), cattle (26\%), dogs (6\%), and horses $(<1 \%)$. Government authorities killed 103 wolves for depredation management. The ratio of wolves killed per domestic animal depredated was higher in Canada that in the United States $\left(\chi^{2}=80.425, p<0.001\right)$.

The number of domestic animals killed by wolves increased in the United States during the study $\left(R^{2}=0.62\right.$, $F=21.60, p<0.001, n=15)$, whereas in Canada it did not (Fig. 1). The number of domestic animals killed each year was correlated with wolves killed by governments in both countries $\left(R^{2}=0.61, F=18.91, p<0.001, n=14\right.$, and $R^{2}=0.92, F=144.04, p<0.001, n=15$, for Canada and the United States, respectively). In the United States, wolves increased during the study $\left(R^{2}=0.79, F=48.61\right.$, $p<0.001, n=15)$, and abundance was correlated with the number of domestic animals killed $\left(R^{2}=0.79, F=\right.$ 48.14, $p<0.001, n=15$ ).

\section{Experiment with Captive Wolves}

During 15 experiments conducted in five enclosures, fladry barriers were effective for up to 28 hours in excluding captive wolves $(n=9)$ from food. Fladry did not prevent two groups of wolves from crossing and reunifying during three social separation experiments in which one wolf had access to food and one or three wolves were on the other side of fladry without food (Table 1). After fladry was removed, the number of crossings between opposite sides of enclosures returned to baseline values. Behavioral analysis performed over the 18 experiments showed that wolves spent more time sniffing in the fladry and post-fladry phases than during the baseline $\left(\chi^{2}=14.245\right.$, $p<0.001, n=9$; baseline-fadry, $Z=2.023, p<0.043$, $n=9$; baseline-postfladry, $Z=3.059, p<0.002, n=$ $9)$. The postfladry phase was characterized by more time spent moving than was the fladry phase $\left(\chi^{2}=12.899\right.$, $p<0.002, n=9$; fladry-postfladry, $Z=3.256, p<0.001$, $n=9)$. Sniffing and moving behaviors were concentrated in the adjacent area (within $2 \mathrm{~m}$ ) on either side of the location occupied by fladry. During the fladry phase, wolves
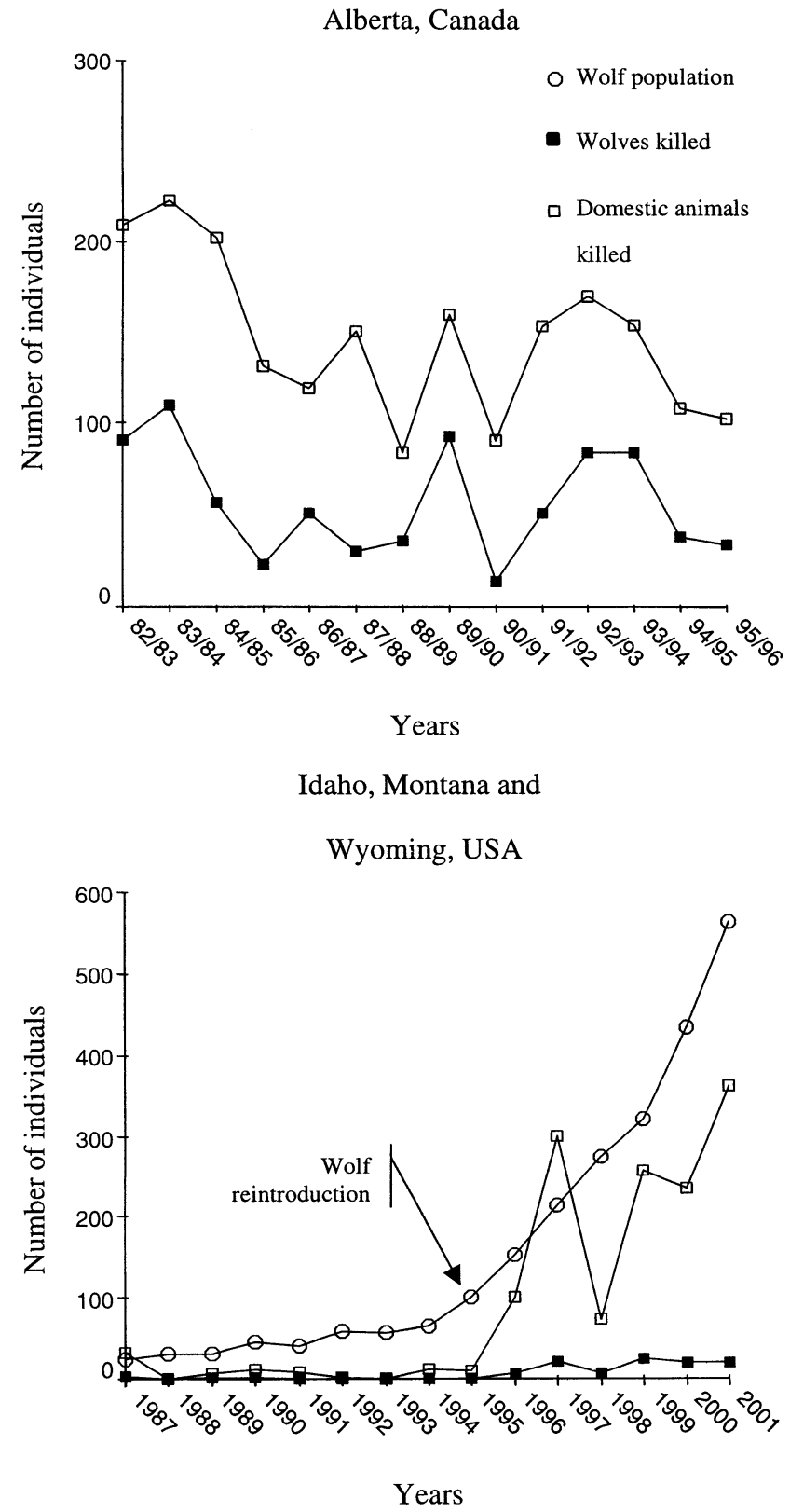

Figure 1. Trends in wolf depredation and wolves killed by government authorities to reduce depredation in Alberta, Canada, and in Idabo, Montana, and Wyoming, United States. Wolf population trends are shown for the U.S. study area.

avoided the area within $6 \mathrm{~m}$ on either side of fladry $\left(\chi^{2}=8.887, p<0.012, n=9\right.$; baseline-fladry, $Z=$ 2.251, $p<0.024, n=9$; fladry-postfladry, $Z=2.685$, $p<0.007, n=9$ ). Throughout the three phases, wolves were equally present within $15 \mathrm{~m}$ of the fladry in the fladry phase. Fladry also allowed temporary separation (10 minutes) of a pair of wolves for administering contraceptives to one of them, while the other wolf received food. This procedure was repeated daily for 8 consecutive days (fladry was removed after 10 minutes). 
Table 1. Individual occurrences of crossings between opposite sides of enclosures $(n=5)$ performed by nine wolves in Popoli, Abruzzo, Italy, 2000-2001. ${ }^{a}$

\begin{tabular}{|c|c|c|c|c|c|}
\hline \multirow[b]{2}{*}{ Experiment type } & \multirow[b]{2}{*}{ Order } & \multirow[b]{2}{*}{ Individual code $^{b}$} & \multicolumn{3}{|c|}{ Crossings } \\
\hline & & & baseline & $\begin{array}{l}\text { fladry (time before } \\
\text { first crossing)c }\end{array}$ & postfladry \\
\hline \multicolumn{6}{|c|}{ 45-minute fladry phase } \\
\hline & 1 & $\mathrm{~W} 1, \mathrm{~W} 2, \mathrm{~W} 3, \mathrm{~W} 4$ & 15 & none & 2 \\
\hline & 2 & $\mathrm{~W} 1, \mathrm{~W} 2, \mathrm{~W} 3, \mathrm{~W} 4$ & 1 & none & 86 \\
\hline \multicolumn{6}{|c|}{ 6-hour fladry phase } \\
\hline & 3 & $\mathrm{~W} 1, \mathrm{~W} 2, \mathrm{~W} 3, \mathrm{~W} 4$ & 26 & none & 80 \\
\hline & 4 & $\mathrm{~W} 1, \mathrm{~W} 2, \mathrm{~W} 3, \mathrm{~W} 4$ & 21 & none & 2 \\
\hline & 5 & $\mathrm{~W} 1, \mathrm{~W} 2, \mathrm{~W} 3, \mathrm{~W} 4$ & 19 & none & 4 \\
\hline & 6 & W5 & 466 & none & 12 \\
\hline & 7 & W5 & none & none & 243 \\
\hline & 8 & W6 & none & none & 3 \\
\hline & 9 & W6 & 10 & none & 17 \\
\hline \multicolumn{6}{|c|}{ 24-hour fladry phase } \\
\hline & 10 & W5 & 388 & none & 1 \\
\hline & 11 & W6 & 24 & none & 7 \\
\hline \multicolumn{6}{|c|}{ 120-hour fladry phase } \\
\hline & 12 & W5 & 94 & none & none \\
\hline & 13 & W6 & 4 & none & none \\
\hline & 14 & W7, w8 & 102 & 28 hours & 23 \\
\hline & 15 & W9 & none & 104 hours & none \\
\hline \multicolumn{6}{|c|}{$\begin{array}{l}\text { 6-hour separation from } \\
\text { food and companion }\end{array}$} \\
\hline & 16 & W1 and food/W2, W3, W4 & 8 & 4.5 hours & 23 \\
\hline & 17 & W1 and food/W2, W3, W4 & 49 & 6 minutes & 2 \\
\hline & 18 & W8 and food/W7 & 60 & 11 minutes & 21 \\
\hline
\end{tabular}

${ }^{a}$ Each experiment consisted of a 45-minute baseline phase, a fladry phase of varying duration in which a fladry barrier was set between wolves and food (experiments 1-15) or to separate wolves from a companion and food (experiments 16-18), and a 45-minute postfladry phase.

${ }^{b}$ Age classes and sex were as follows: W1, adult female; W2, adult male; W3 and W4, pups, unknown sex; W5, adult female; W6, adult male; W7, adult female; $W 8$, adult male; and W9, adult female.

${ }^{c}$ The fladry phase was suspended whenever the first crossing occurred.

\section{Baited Stations}

In southwestern Alberta, we conducted field experiments with fladry in a region where wolves had killed 173 domestic animals between 1990 and 2001. Cattle constituted the majority of kills (95\%). Fladry impeded access by wild wolves to $100-\mathrm{m}^{2}$ baited sites during two 60-day tests (Table 2).

\section{Cattle Pastures}

During two 60-day field trials in which 25-ha cattle pastures were enclosed with fladry, we detected 23 wolf approaches to within $50 \mathrm{~m}$ of the barriers, of which 14 were within $1 \mathrm{~m}$, but there were no crossings and no killings (Table 2). Wolves killed seven cattle in the 2 months before the trials and two cattle in the 2 months after on the two properties where we conducted the fladry experiments. Neighboring ranches experienced livestock losses due to wolves throughout the period of our experiments.

In Idaho radiocollared wolves were located denning within a 400-ha ranch during the spring of 2002. During the summer of 2002, we surrounded the ranch with fladry barriers, which the wolves crossed from the outside after 61 days. The wolves killed cattle in the enclosed ranch some time during a 72-hour period. In response to a complaint from the producer, a helicopter was dispatched to kill the wolves. The wolves exited the enclosure when chased by the helicopter. Similar to what we observed in Alberta, the wolves killed livestock on neighboring ranches during the experiment. One or two researchers walked the fladry line to maintain it every 72 hours. Maintenance consisted of repositioning flags that became wrapped around the existing barbwire fence to which the fladry line was attached and reapplying flags that were removed by cattle. Maintenance was not required for the Alberta trails because fladry was set outside the fence confining cattle.

\section{Discussion}

\section{Wolf-Depredation Trends in Western Canada and United States}

Wolf depredation on domestic animals varied between the United States, where sheep were the primary 
Table 2. Number of approaches by wolves and depredation or feeding by wolves on cattle or baits during fladry trials conducted in southwestern Alberta, Canada. ${ }^{a}$

\begin{tabular}{|c|c|c|c|c|c|c|}
\hline \multirow[b]{2}{*}{ Experiment ${ }^{b}$} & \multicolumn{2}{|c|}{ Baseline } & \multicolumn{2}{|c|}{ Fladry phase } & \multicolumn{2}{|c|}{ Postfladry } \\
\hline & approacbes & $\begin{array}{l}\text { depredation } \\
\text { or feeding }\end{array}$ & approaches & $\begin{array}{l}\text { depredation } \\
\text { or feeding }\end{array}$ & approacbes & $\begin{array}{c}\text { depredation } \\
\text { or feeding }\end{array}$ \\
\hline Cattle pasture $1^{c}$ & 2 & 2 & 17 & none & 2 & 2 \\
\hline Cattle pasture $2^{c}$ & 7 & 5 & 6 & none & 2 & none \\
\hline Bait site $1^{d}$ & 16 & 16 & 16 & none & none & none \\
\hline Bait site $2^{d}$ & 28 & 28 & 18 & none & none & none \\
\hline Total & 53 & 51 & 57 & none & 4 & 2 \\
\hline
\end{tabular}

${ }^{a}$ Trials were divided into three 60-day phases, including baseline, fladry, and postfladry.

${ }^{b}$ Conducted at nonoverlapping times.

c25-ha areas located $150 \mathrm{~km}$ apart.

${ }^{d} 100-\mathrm{m}^{2}$ areas located $100 \mathrm{~km}$ apart.

prey, and Canada, where sheep were the fourth mostdepredated species. This difference likely reflects the rarity of sheep grazing on public lands in Canada, where the majority of wolf-depredation events (57\%) occurred. There are no sheep grazed on public dispositions in the forested areas in the southwestern corner of Alberta. Most sheep production occurs in the south-central and southeastern agricultural areas of Alberta, in which there is a greater proportion of private land and virtually no wolves (Carbyn 1983; Hayes \& Gunson 1995).

Contrary to trends in Canada, in the United States the number of wolves killed by people and the occurrences of wolf depredations are increasing. These trends are related to concurrent increases in the wolf population in the United States. Interestingly, the numbers of domestic animals and wolves killed were strongly correlated in both countries. In Canada, however, government authorities killed more wolves to manage depredation.

Our data on the number of wolves killed by government authorities in relation to the number of domestic animals killed by wolves may indicate that human tolerance of wolves was greater in the United States ( 14 wolves killed for 100 domestic animals) than in Canada (38 wolves for 100 domestic animals). This may reflect differences in the legal status of wolves and the recent initiative to recover the wolf population in the western United States (Fritts et al. 1997; Bangs et al. 1998), as well as positive attitudes toward wolves (Kellert et al. 1996; Williams et al. 2002; Naughton et al. 2003 [this volume]). In Alberta the wolf is not listed as a threatened species (Committee on the Status of Endangered Wildlife in Canada 2002), and lethal management is practiced to reduce depredation on livestock (Gunson 1992; Cluff \& Murray 1995; Hayes \& Gunson 1995). In Idaho, Montana, and Wyoming, as in most other U.S. states, the federal Endangered Species Act has effectively protected wolves since 1973, although some illegal killing has occurred (Fuller 1989; Treves et al. 2002). In addition, the U.S. government kills depre- dating wolves in Minnesota (Fritts et al. 1992). The larger population size and nonendangered status of wolves in Alberta or Minnesota than in the northwestern United States might allow for lethal control with less risk to population survival.

We forecast that, in the United States, further increases in wolf population numbers will be accompanied by increased depredation on domestic animals and subsequently will lead to increased demands for lethal wolf control. In April 2003, the U.S. Fish and Wildlife Service reclassified gray wolf populations under the Endangered Species Act (U.S. Fish and Wildlife Service 2000, 2003). The most significant change is the downlisting of endangered wolf populations to the threatened category in the conterminous United States. Reclassification of wolves allows for more flexibility in control by federal agencies.

\section{Fladry Effectiveness in Food Experiments}

Our experiments provided insights into the capability of fladry to interfere with wolf foraging behavior. Our results demonstrated that fladry is effective in preventing captive wolves from accessing food for more than 1 day of deprivation. Fladry was not effective when it obstructed access to both food and group members. Our results suggest that wolf avoidance of fladry decreases when food attraction is coupled with the stress associated with social separation (sensu Ruiz-Miranda et al. 1998; Tarou et al. 2000). Socialseparation or food-deprivation stimuli were not strong enough to induce wolves to cross fladry. The alternative hypothesis that separation stress and the fear of novel objects (Bronson 1968) inhibited crossings remains unexamined. Some novel barriers other than fladry and/or the scent left by researchers do not impede wolf movements in captivity (Musiani \& Visalberghi 2001). Further research is needed to determine whether other objects with various design attributes are capable of effects similar to those described for fladry. 
Wolf-location data indicated avoidance of the 6-m area adjacent to fladry. This behavior confirms that the wolves were fearful of the structure. Wolves continued to investigate fladry throughout the trials, however, which we interpret as testing the structure for opportunities to cross (i.e., searching for possible breaks or interruptions of the barrier). Once fladry was removed, wolves again used the area formerly occupied by fladry and increased their rate of movement there.

Fladry was a useful tool for restricting movements of captive wolves. Possible applications include frequently used practices with zoo animals, such as separating individuals for diet management (Cook et al. 2001), selective breeding (Schreiber et al. 1993), or individual pharmacological treatments (Ortiz et al. 2001, 2003 [this study]).

\section{Protecting Livestock with Fladry}

Our results with baited sites and cattle pastures in Alberta suggest that wild wolves can be effectively excluded for at least 60 days from food sources and smaller areas ( $\leq 25$ ha) by fladry barriers. However, we could not rule out the alternative hypothesis that the fear of novelty (Bronson 1968), coupled with our presence while monitoring the fladry perimeter, exerted the effect.

The effectiveness of fladry for protecting larger areas is not understood as well, although our results from Idaho (400-ha ranch) indicate fladry may be useful for periods of at least 60 days. During the trial in Idaho, some fladry flags either got wrapped around the barbed wire on which fladry was attached or were pulled off by cattle. Thus, fladry was not deployed under optimal design conditions throughout the perimeter. Hair samples on the barbedwire fence indicated wolves could have crossed at these gaps. In addition, the odor left by cattle on the fladry equipment could have confounded the results by covering human odor or by attracting wolves. Such problems did not occur in Alberta because fladry was set $2 \mathrm{~m}$ outside existing cattle fences. Musiani and Visalberghi (2001) showed that gaps of $\geq 1 \mathrm{~m}$ between fladry flags (equivalent to removal of just one flag) were enough to allow for wolf crossing in captivity. Maintaining fladry lines in optimal conditions likely maximizes the effectiveness of the fladry, but doing so will be logistically difficult over a large area.

During our experiments, wolves killed cattle on neighboring ranches in both Alberta and Idaho. We speculate that the presence of available prey outside the fladry boundary is critical for enhancing its effectiveness. In particular, if wild prey is scarce, fladry may be ineffective when applied on large properties and/or on several contiguous pastures. Optimal foraging theory suggests that an animal will maximize its overall net rate of energy gain by departing from a given resource patch when its net rate of energy gain (profitability) is reduced to the level or value of the next most profitable patch (Charnov 1976; Kie
1999; Nolet 2002). We suggest that fladry reduces patch profitability by increasing the time invested in testing prey vulnerability. Therefore, wild wolves should leave to seek alternative prey and should not risk crossing fladry. In captivity, wolves appear to be willing to risk crossing fladry only after an extended period of food deprivation (>28 hours). The limited duration of fladry's effectiveness in captivity suggests it would also be only temporarily effective for the management of wolves in nature.

Our data on wolf depredation and management actions to remove wolves indicate that protecting domestic animals from wolves might reduce the necessity of killing wolves as a management response. Killing of wolves is a concern in areas where wolves are threatened or endangered (Hilton-Taylor 2000) or where their social behavior is being studied (Haber 1996). In both the Eurasian and North American ranges of the wolf, programs are in place in various jurisdictions, including our study area, to compensate livestock producers for economic losses caused by wolf depredation (Gunson 1992; Ciucci \& Boitani 1998; Phillips \& Smith 1998; Alberta Conservation Association 2002; Treves et al. 2002). In spite of this, compensation may not be socially and economically sustainable in the long term. Costs may increase because of abandonment of preventive husbandry practices, and communities may refuse to bear increased costs (Mech 1998). Therefore, some authors suggest that compensation programs should be designed in combination with incentives to encourage preventive management (Cozza et al. 1996; Poulle et al. 1997; Ciucci \& Boitani 1998). A prevalent societal goal is to make values such as livestock production less accessible to carnivores. Fladry could play a role among the limited set of preventive measures available and offers a cost-effective mitigation tool for the problem of wolf depredation on livestock on a local scale.

Our results indicate that fladry is useful for temporarily protecting livestock from wolves when livestock is kept in small pastures. Livestock is frequently confined in such pastures for calving, lambing (Fritts et al. 1992), overnight holding (Gipson \& Paul 1994), or rotational grazing (Heady 1975). We recommend that further research be conducted before applying fladry on a large scale. Novel objects other than fladry should be tested to compare their efficacy and cost-effectiveness. In addition, field experiments should be conducted in which fladry and other objects are tested without researchers monitoring the structures on foot-with video cameras, for example. Remote monitoring would allow for distinguishing between avoidance of people and avoidance of fladry. Other variables remaining to be tested include habituation to fladry in the long term and the influence of alternative prey abundance in the test area. Finally, fladry might affect wolf survival by making domestic food sources unavailable or by forcing wolves to use suboptimal habitat. 


\section{Acknowledgments}

We acknowledge the help of the ranching community of Alberta and Idaho, the Alberta Cattle Commission, Alberta Sustainable Resource Development (SRD) and Community Development (CD), the National Wildlife Research Center of the U.S. Department of Agriculture Wildlife Services, the U. S. Fish and Wildlife Service, Lisa Arsenault, E. Bangs, S. Bertollo, C. Bergman, J. Bews, L. Bradley, R. Bryant, E. and F. Coiner, S. D'Alessio, S. Donelon, J. Fontaine, C. Hague, S. Hawes, D. and L. Glaister, M. Going, G. Hoffman, M. Jimenez, L. Jones, J. Jorgenson, T. Kaminsky, S. Laverty, C. Mack, T. Mack, T. Meier, M. Main, C. Niemeyer, K. Olchowy, T. Partello, C. Powell, M. Rulli, G. Sargent, E. Surridge, and R. Williamson. Wolf population and depredation statistics were obtained through Alberta SRD and CD and the U.S. Fish and Wildlife Service, the Nez Perce Tribe, the U.S. National Park Service, and the U.S. Department of Agriculture Wildlife Service. We acknowledge support from the Alberta Conservation Association, Alberta Community Lotteries Fund, Alberta Ecotrust, Calgary Foundation, Calgary Zoo, Defenders of Wildlife, Humane Society of the United States, Kendall Foundation, Shell Environment Fund, Summerlee Foundation, Toronto Dominion Friends of the Environment, Wilburforce Foundation, and YtoY. M.M. was supported by Honourary Killam, National Sciences and Engineering Research Council of Canada, and Consiglio Nazionale delle Ricerche, Italy. We acknowledge A. Treves, K. Ullas Karanth, the Center for Applied Biodiversity Science, and Conservation International for organizing the symposium "Human-Carnivore conflict: Local Solutions with Global Applications," held at the 16th annual meeting of the Society for Conservation Biology. We are grateful to $\mathrm{C}$. Promberger and an anonymous reviewer for their suggestions for the manuscript.

\section{Literature Cited}

Alberta Conservation Association (ACA). 2002. 2001/02 annual report. ACA, Edmonton, Alberta. Available from http://www.abconservation.com/yourdollarsatwork/annualreport/(accessed September 2002).

Andelt, W. F., and S. N. Hopper. 2000. Livestock guard dogs reduce predation on domestic sheep in Colorado. Journal of Range Management 53:259-267.

Bangs, E., and J. Shivik. 2001. Managing wolf conflict with livestock in the northwestern United States. Carnivore Damage Prevention News 3:2-5

Bangs, E. E., S. H. Fritts, J. A. Fontaine, D. W. Smith, K. M. Murphy, C. M. Mack, and C. C. Niemeyer. 1998. Status of gray wolf restoration in Montana, Idaho, and Wyoming. Wildlife Society Bulletin 26:785798.

Berg, K. A. 1998. The future of the wolf in Minnesota: control, sport or protection? Pages 40-44 in Proceedings of the Defenders of Wildlife's restoring the wolf conference. Defenders of Wildlife, Washington, D.C.

Boyd, D. K., R. R. Ream, D. H. Pletscher, and M. W. Fairchild. 1994. Prey taken by colonizing wolves and hunters in the Glacier-National-Park area. Journal of Wildlife Management 58:289-295.

Bronson, G. W. 1968. The fear of novelty. Psychological Bulletin 69:350358.

Carbyn, L. N. 1983. Wolves in Canada and Alaska: their status, biology and management. Report: series 45. Canadian Wildlife Service, Ottawa.

Charnov, E. L. 1976. Optimal foraging: the marginal value theorem. Theoretical Population Biology 9:129-136.

Ciucci, P., and L. Boitani. 1998. Wolf and dog depredation on livestock in central Italy. Wildlife Society Bulletin 26:504-514.

Cluff, H. D., and D. L. Murray. 1995. Review of wolf control methods in North America. Pages 491-607 inL. N. Carbyn, S. H. Fritts, and D. R. Seip, editors. Ecology and conservation of wolves in a changing world. Occasional publication 35. Canadian Circumpolar Institute, University of Alberta, Edmonton.

Committee on the Status of Endangered Wildlife in Canada. 2000. Canadian species at risk. Government of Canada, Ottawa, Ontario. Available from http://www.cosewic.gc.ca/cosewic/cosewiclist.pdf (accessed September 2002).

Cook, R. C., D. L. Murray, J. G. Cook, P. Zager, and S. Monfort. 2001. Nutritional influences on breeding dynamics in elk. Canadian Journal of Zoology 79:845-853.

Coppinger, R., and L. Coppinger. 2001. Dogs: a new understanding of canine origin, behavior and evolution. The University of Chicago Press, Chicago.

Cozza, K., R. Fico, M. L. Battistini, and E. Roogers. 1996. The damageconservation interface illustrated by predation on domestic livestock in central Italy. Biological Conservation 78:329-336.

Fritts, S. H., and W. J. Paul. 1989. Interactions of wolves and dogs in Minnesota. Wildlife Society Bulletin 17:121-123.

Fritts, S. H., W. J. Paul, and L. D. Mech. 1984. Movements of translocated wolves in Minnesota. Journal of Wildlife Management 48:709-721.

Fritts, S. H., W. J. Paul, L. D. Mech, and D. P. Scott. 1992. Trends and management of wolf-livestock conflicts in Minnesota. Resource publication 181. U.S. Fish and Wildlife Service, Washington, D.C.

Fritts, S. H., E. E. Bangs, J. A. Fontaine, M. R. Johnson, M. K. Phillips, E. D. Koch, and J. R. Gunson. 1997. Planning and implementing a reintroduction of wolves to Yellowstone National Park and central Idaho. Restoration Ecology 5:7-27.

Fuller, T. K. 1989. Population dynamics of wolves in north-central Minnesota. Wildlife Monograph 105.

Gipson, P. S., and W. J. Paul. 1994. Wolves: prevention and control of wildlife damage. U. S. Department of Agriculture, Great Plains Agricultural Council, University of Nebraska Press, Lincoln.

Gunson, J. R. 1992. Historical and present management of wolves in Alberta. Wildlife Society Bulletin 20:330-339.

Haber, G. C. 1996. Biological, conservation, and ethical implications of exploiting and controlling wolves. Conservation Biology 10:10681081.

Hansen, I., and M. E. Smith. 1999. Livestock-guarding dogs in Norway. II. Different working regimes. Journal of Range Management 52:312316.

Hayes, R. D., and J. R. Gunson. 1995. Status and management of wolves in Canada. Pages 21-33 inL. N. Carbyn, S. H. Fritts, and D. R. Seip, editors. Ecology and conservation of wolves in a changing world. Occasional publication 35. Canadian Circumpolar Institute, University of Alberta, Edmonton.

Heady, H. F. 1975. Rangeland management. McGraw-Hill, New York.

Hilton-Taylor, C. 2000. 2000 IUCN red list of threatened species. World Conservation Union, Gland, Switzerland.

Jedrzejewski, W., K. Schmidt, J. Theuerkauf, B. Jedrzejewska, N. Selva, K. Zub, and L. Szymura. 2002. Kill rates and predation by wolves on ungulate populations in Bialowieza Primeval Forest (Poland). Ecology 83:1341-1356.

Kay, C. E. 1998. Are ecosystems structured from the top-down or bottom-up: a new look at an old debate. Wildlife Society Bulletin 26:484-498. 
Kellert, S. R., M. Black, C. R. Rush, and A. J. Bath. 1996. Human culture and large carnivore conservation in North America. Conservation Biology 10:977-990.

Kie, J. G. 1999. Optimal foraging and risk of predation: effects on behavior and social structure in ungulates. Journal of Mammalogy 80:1114-1129.

Kojola, I., and J. Kuittinen. 2002. Wolf attacks on dogs in Finland. Wildlife Society Bulletin 30:498-501.

Linnell, J. D. C., R. Aanes, J. E. Swenson, J. Odden, and M. E. Smith. 1997. Translocation of carnivores as a method for managing problem animals: a review. Biodiversity Conservation 6:1245-1257.

Linnell, J. D. C., J. E. Swenson, and R. Andersen. 2000. Conservation of biodiversity in Scandinavian boreal forests: large carnivores as flagships, umbrellas, indicators, or keystones? Biodiversity Conservation 9:857-868.

Madhusudan, M. D., and K. U. Karanth. 2002. Local hunting and the conservation of large mammals in India. Ambio 31:49-54.

Mech, L. D. 1970. The wolf: ecology and behaviour of an endangered species. Natural History Press, New York.

Mech, L. D. 1995. The challenge and opportunity of recovering wolf populations. Conservation Biology 9:270-278.

Mech, L. D. 1998. Estimated costs of maintaining a recovered wolf population in agricultural regions of Minnesota. Wildlife Society Bulletin 26:817-822.

Mech, L. D., E. K. Harper, T. J. Meier, and W. J. Paul. 2000. Assessing factors that may predispose Minnesota farms to wolf depredations on cattle. Wildlife Society Bulletin 28:623-629.

Meriggi, A., and S. Lovari. 1996. A review of wolf predation in southern Europe: does the wolf prefer wild prey to livestock? Journal of Applied Ecology 33:1561-1571.

Musiani, M., and E. Visalberghi. 2001. Effectiveness of fladry on wolves in captivity. Wildlife Society Bulletin 29:91-98

Nolet, B. A. 2002. Efficiency as a foraging currency in animals attaining a gain below the energetic ceiling. Behavioral Ecology 13:571-574.

Okarma, H. 1993. Status and management of the wolf in Poland. Biological Conservation 66:153-158.

Okarma, H., and W. Jedrzejewski. 1997. Livetrapping wolves with nets Wildlife Society Bulletin 25:78-82.

Orians, G. H., et al. 1997. Wolves, bears, and their prey in Alaska: biological and social challenges in wildlife management. National Academy Press, Washington, D.C.

Ortiz, J., M. R. R. De Ybañez, T. Abaigar, M. Goyena, G. Espeso, M. Cano, and F. Alonso. 2001. Effect of different methods of administration of ivermectin on its efficacy against the shedding of gastrointestinal nematode eggs by gazelles. Veterinary Record 149:12-15.

Parsons, D. R. 1998. "Green fire" returns to the Southwest: reintroduction of the Mexican wolf. Wildlife Society Bulletin 26:799-807.

Phillips, M. K., and D. W. Smith. 1998. Gray wolves and private landowners in the Greater Yellowstone area. Transactions of the North American Wildlife and Natural Resources Conference 63:443-450.

Poulle, M. L., L. Carles, and B. Lequette. 1997. Significance of ungulates in the diet of recently settled wolves in the Mercantour mountains (southeastern France). Revue d'Ecologie-La Terre et la Vie 52: 357 368 .

Ripple, W. J., E. J. Larsen, R. A. Renkin, and D. W. Smith. 2001. Trophic cascades among wolves, elk and aspen on Yellowstone National Park's northern range. Biological Conservation 102:227-234.

Ruiz-Miranda, C. R., S. A. Wells, R. Golden, and J. Seidensticker. 1998. Vocalizations and other behavioral responses of male cheetahs ( $\mathrm{Aci}$ nonyx jubatus) during experimental separation and reunion trials. Zoo-Biology 17:1-16.

Schreiber, A., L. Kolter, and W. Kaumanns. 1993. Conserving patterns of genetic diversity in endangered mammals by captive breeding. Acta Theriologica 38:71-88.

Sillero-Zubiri, C., and M. K. Laurenson. 2001. Interactions between carnivores and local communities: conflict or co-existence? Pages 282312 in J. L. Gittleman, S. M. Funk, D. W. MacDonald, and R. K. Wayne, editors. Carnivore conservation. Cambridge University Press, Cambridge, United Kingdom.

Smith, M. E., J. D. C. Linnell, J. Odden, and J. E. Swenson. 2000a. Review of methods to reduce livestock depredation. I. Guardian animals. Acta Agriculturae Scandinavica, Section A: Animal Sciences 50:279290.

Smith, M. E., J. D. C. Linnell, J. Odden, and J. E. Swenson. 2000b. Review of methods to reduce livestock depredation II. Acta Agriculturae Scandinavica, Section A: Animal Sciences 50:304-315.

Struzik, E. 1993. Managing the competition: wolves are at the centre of a wildlife management controversy. Nature Canada 22:22-27.

Tarou, L. R., M. J. Bashaw, and T. L. Maple. 2000. Social attachment in giraffe: response to social separation. Zoo-Biology 19:41-51.

Treves, A., R. R. Jurewicz, L. Naughton-Treves, R. A. Rose, R. C. Willging, and A. P. Wydeven. 2002. Wolf depredation on domestic animals in Wisconsin, 1976-2000. Wildlife Society Bulletin 30:231-241.

U.S. Fish and Wildlife Service (USFWS). 2000. Proposal to reclassify and remove the gray wolf from the list of endangered and threatened wildlife in portions of the conterminous United States; proposal to establish three special regulations for threatened gray wolves; proposed rule. Federal Register 65:43449-434496.

U.S. Fish and Wildlife Service (USFWS). 2003. Endangered and threatened wildlife and plants; final rule to reclassify and remove the gray wolf from the list of endangered and threatened wildlife in portions of the conterminous United States; establishment of two special regulations for threatened gray wolves; final and proposed rules. Federal Register 68:15803-15875.

Williams, C. K., G. Ericsson, and T. A. Heberlein. 2002. A quantitative summary of attitudes toward wolves and their reintroduction (19722000). Wildlife Society Bulletin 30:575-584.

Woodroffe, R. 2000. Predators and people: using human densities to interpret declines of large carnivores. Animal Conservation 3:165173.

Young, S. P., and E. A. Goldman. 1944. The wolves of North America. Dover, New York.

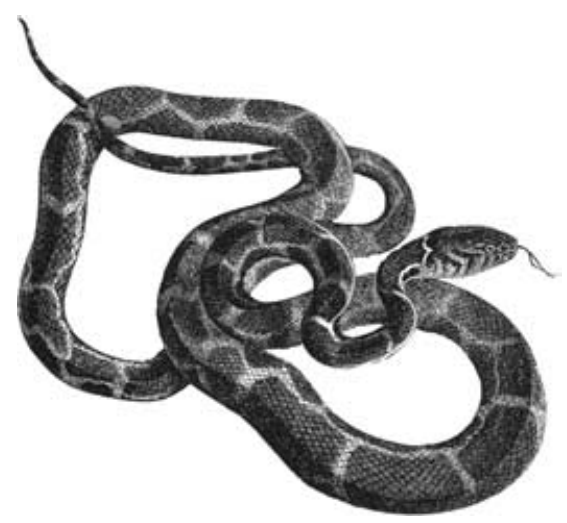

